\title{
EFFECT OF FEEDING CORN SILAGE DURING FINISHING PERIOD ON PHYSICAL AND CHEMICAL TRAITS OF BALADI BULLOCKS MEAT
}

\author{
Amal K. El-Asheeri \\ Department of Animal Production, Faculty of Agriculture, University of Cairo, \\ 12613, Giza, Egypt
}

\section{SUMMARY}

Sixteen Baladi bullocks were used to study the effect of feeding corn silage during finishing period on chemical and physical traits of meat. Fattening period was divided into two phases: phase I (growing period) started with body weight (BW) of $220-230 \mathrm{~kg}$ and extended up to $360-370 \mathrm{~kg}$, while phase II (finishing period, FP) started after phase I and extended up to $430 \mathrm{~kg}$. During phase I animals were fed on concentrate feed mixture (CFM) and corn silage (CS) at a ratio of 1:3. During phase II animals were divided into two equal groups. The $1^{\text {st }}$ group (G1) continued on feeding the same ration of phase I, while the $2^{\text {nd }}$ group (G2) was fed CFM plus rice straw. At the end of the experiment, animals were slaughtered to study carcass characteristics as well as physical and chemical traits of meat. Some economic indicators (feed conversion, finishing period, and cost of feeding to produce $1 \mathrm{~kg}$ gain) were also estimated. The $A D G$ was higher $(P<0.01)$ in $G 2(0.87 \pm 0.05 \mathrm{~kg})$ compared to G1 $(0.62 \pm 0.05 \mathrm{~kg})$, while FP was longer $(P<0.001)$ in $G 1(102.0 \pm 7.8 \mathrm{~d})$ relative to $G 2(80.2 \pm 3.5$ d) by about $25 \%$. Carcass characteristics as well as chemical and physical traits of meat were similar in the two studied groups. Cost of feed/ $\mathrm{kg}$ gain of $G 1$ was less $(P<0.05)$ than of $G 2$ by $29.5 \%$. In conclusion, feeding Baladi bullocks during the finishing period on corn silage has improved economic indicators with no negative impact on meat quality.

Keywords: Baladi cattle, feeding, finishing, carcass and meat characteristics

\section{INTRODUCTION}

Baladi cattle are the Egyptian native cattle breed. They are characterized with low milk yield of 0.64-1.2 ton/ lactation (Mostageer et al., 1987; 1990) Accordingly they are mainly reared as meat producers. Physical and chemical traits of meat are the two major factors determining meat quality. Tenderness and juiciness represent to a great extent the physical quality of meat, while chemical composition settles on its nutritive value.

Fattening process is usually ended by a finishing period to improve animals' phenotype before marketing, dressing percentage and meat quality. Under the Egyptian conditions, finishing weight of Baladi bullocks started between 350 to 370 up to 400 to $430 \mathrm{~kg}$.

Many studies were conducted to study meat quality of beef breeds under different systems of feeding (Tøgersen et al., 2003; Sami et al., 2004, Prieto et al., 2006;

Issued by The Egyptian Society of Animal Production 
Faucitano et al., 2008 and Jenschke et al., 2008). Effect of type of feeding on physical and chemical traits of meat showed contradicted trends. O'Sullivan et al. (2003); Faucitano et al. (2008); Gill et al. (2008) reported no effect of feeding type on physical and chemical characteristics of meat of fattening animals, while French et al. (2000); and Jenschke et al. (2008) reported that type of feeding affects the physical and chemical prosperities of the produced meat.

In Egypt, Sadek et al. (1993); El- Bedawy et al. (2004) and El-Asheeri (2008) studied the growth features of fattened Baladi bullocks when feeding concentrate feed mixture, or when replacing part of concentrate feed mixture by protected fat (ElBedawy et al., 1996) or corn silage (El- El-Asheeri et al., 2008). On the contrast, few studies (El-Bedawy et al., 1996) were made available to show the effect of feeding during the finishing period on meat traits.

Currently fattening animals on corn silage is adopted to reduce the cost of $1 \mathrm{~kg}$ gain; meanwhile there is a lack of information concerning the effect of feeding corn silage during finishing period on carcass characteristics as well as physical and chemical traits of meat of Baladi bullocks, which was the aim of this study.

\section{MATERIALS AND METHODS}

\section{Animals and management:}

The present study was carried in the Agriculture Experimental Station, Faculty of Agriculture, Cairo University,Giza, Egypt on 16 Baladi bullocks. Animals were purchased from the local market with body weight (BW) of $220-230 \mathrm{~kg}$. Fattening period (from purchasing to slaughter) was divided into two phases. Phase I started upon purchasing and continued up to BW of $360-370 \mathrm{~kg}$, while phase II (finishing period) started from the end of phase I up to $430 \mathrm{~kg}$ (final body weight).

During phase I, the experimental animals were fed on concentrate feed mixture (CFM) and corn silage (CS) at a ratio of 1:3. During phase II animals were divided into two equal groups, 8 animals each. The $1^{\text {st }}$ group $(\mathrm{G} 1)$ had a BW of $366.8 \pm 2.0$ $\mathrm{kg}$ and was fed on the same ration of phase I, while the $2^{\text {nd }}$ group (G2) (365.6 \pm 2.6 $\mathrm{kg}$ ) was fed on non-pelted CFM plus rice straw. Feeding practice during both phases was based on animals BW according to NRC (1996) requirements. Averages of offered feedstuffs / head / day during phase I were $2.2 \pm 0.03 \mathrm{~kg}$ CFM and 14.5+ $0.2 \mathrm{~kg}$ corn silage/day. The averages of feedstuffs/head/day during phase II were $2.34 \pm 0.11 \mathrm{~kg}$ CFM plus $22.85 \pm 0.6 \mathrm{~kg} \mathrm{CS}$ for G1 and $6.1 \pm 0.52 \mathrm{~kg}$ CFM and $3.94 \pm 0.03 \mathrm{~kg}$ rice straw for G2. Chemical composition of feedstuffs used in the study (Table 1) was analyzed according to A.O.A.C. (1990). Animals were kept tethertied throughout the experimental period in a semi open yard and were offered water twice daily.

Table 1. Chemical composition (\%) of concentrate feed mixture (CFM), corn silage (CS) and rice straw (RS) used in feeding the experimental animals

\begin{tabular}{lccc}
\hline Items & CFM & CS & RS \\
\hline Dry matter & 92.0 & 34.0 & 90.0 \\
Crude protein & 15.0 & 8.0 & 3.5 \\
Ether extract & 4.4 & 6.1 & 1.0 \\
Crude fiber & 9.2 & 16.0 & 40.0 \\
Nitrogen -free extract & 62.1 & 60.9 & 50.0 \\
Ash & 9.3 & 9.0 & 6.0 \\
\hline
\end{tabular}




\section{Experimental procedure and measured data:}

At the end of the experiment six bullocks from each group were chosen randomly to be slaughtered. Bullocks were slaughtered after $18 \mathrm{hr}$ fasting period. Animals were skinned, eviscerated and sectioned down through the vertebral column into two halves. The rib cut $\left(9,10\right.$ and $11^{\text {th }}$ ribs) was separated from left side of the carcass to characterize physical and chemical traits of meat of Longissimus dorsi. After measuring eye muscle area $\left(\mathrm{cm}^{2}\right)$, meat was kept frozen at $-20^{\circ} \mathrm{C}$ until analysis.

Weight of hot carcass $(\mathrm{kg})$, dressing percentage (carcass weight / final body weight $\times 100$ ), boneless meat percentage (Meat weight / final body weight $\times 100$ ), and the physical components of rib cut were determined as carcass traits. Percentages of moisture, protein, fat and collagen were determined using meat analyzer (Foss analytical A/S, Model 78810, Denmark) as chemical traits according to the procedure outlined by the manufacturer.

To determine the percentage of expressible fluid (\%), a meat sample of $0.3 \mathrm{gm}$ (W1) was placed on a filter paper (Whatman No.1) and then subjected to a pressure of $1000 \mathrm{gm}$ for 10 minutes. The sample was weighed afterwards (W2) and the expressible fluid was estimated as the difference between the two weights divided by W1 multiplied by 100 .

Cooking loss was determined using 2 cubes of meat (100 gm, W1). The samples were boiled in saline $(0.9 \% \mathrm{NaCl})$ for 45 minutes, and then were left to down cool at room temperature. Samples were re-weighed (W2) to calculate the cooking loss percentage as the difference between W1 and W2 divided by W1 multiplied by 100 .

Cooked samples were used for estimating shear force ( $\mathrm{kg} /$ force). After keeping in refrigerator $\left(4-5^{\circ} \mathrm{C}\right)$ for about $12 \mathrm{hr}$, six cores from each sample were removed parallel to longitudinal orientation of muscle fibers using a cylinder of 0.5 inch in diameter. Shear force were measured using Instron Universal Testing Machine (Model 2519-105, USA), which was adjusted at a cross head speed of $200 \mathrm{~mm} / \mathrm{min}$ according to Shackelford, $(1999 ; 2004)$.

Meat color was measured using Croma meter (Konica Minolta, model CR 410, Japan). Color was expressed using the CIE L*, $a^{*}$, and $b^{*}$ color system (CIE, 1976). A total of three spectral readings were taken for each sample on three locations of the muscle. $\mathrm{L}^{*}$ values measure lightness (white to black color); $\mathrm{a}^{*}$ values measure redness (red to green color); and $b^{*}$ values measure yellowness (yellow to blue color).

The $\mathrm{pH}$ values before ( $3 \mathrm{hr}$ post- slaughter) and after chilling ( $24 \mathrm{hr}$ postslaughter) were measured using $\mathrm{pH}$ meter ( $\mathrm{pH}$ ep, HI 96107, Hanna instruments, Italy).

Finishing period (the interval from starting finishing period to reaching the final body weight, day), average daily gain (total gain in $\mathrm{kg} /$ fattening period, day), and cost of feeding/ $\mathrm{kg}$ gain (LE) were calculated as economic indicators.

\section{Technical coefficients:}

Based on local market price of feedstuffs (Egyptian pound, LE) during year 2008, the price list used was as follows:

- Price of concentrate mixture $=$ L.E $1450 /$ ton

- Price of corn silage $\quad=$ L.E $200 /$ ton

- Price of rice straw = L.E $130 /$ ton 


\section{Statistical analysis:}

Data were statistically analyzed using SAS (2001). Data in percentages were transformed to the arcsine square-root to normalize variance before analysis. The model used was as follows:

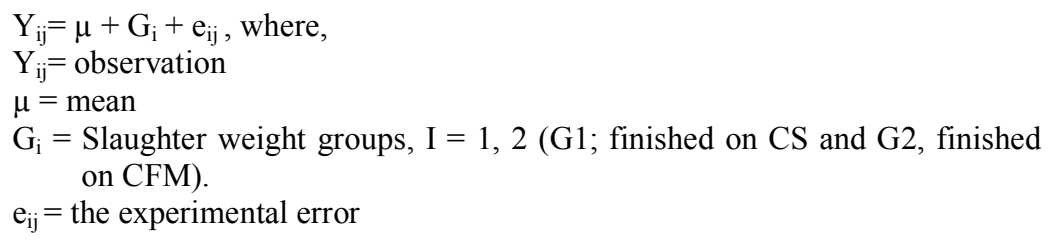

\section{RESULTS AND DISCUSSION}

\section{Growth and carcass data:}

Type of feeding has a significant effect on finishing period $(\mathrm{P}<0.001)$ and average daily gain $(\mathrm{P}<0.01)$ as shown in Table 2 . Fattening period was shorter and average daily gain (ADG) was higher in G1compared to G2. Finishing period of G1 was longer than of G2 by about $21 \%$, while ADG of G2 was higher than of G1 by $29 \%$. Type of feeding during finishing period had no effect on all the studied carcass traits and rib cut components (Table 3 ).

Table 2. Growth traits (mean $\pm \mathrm{SE}$ ) during finishing period of Baladi bullocks as affected by type of feeding

\begin{tabular}{lccc}
\hline Trait & G1 & G2 & P value \\
\hline Initial body weight $(\mathrm{kg})$ & $366.8 \pm 2.0^{\mathrm{a}}$ & $365.6 \pm 2.6^{\mathrm{a}}$ & 0.7 \\
Final body weight $(\mathrm{kg})$ & $428.8 \pm 4.3^{\mathrm{a}}$ & $434.8 \pm 2.0^{\mathrm{a}}$ & 0.3 \\
Finishing period (day) & $102.0 \pm 7.8^{\mathrm{a}}$ & $80.2 \pm 3.5^{\mathrm{b}}$ & 0.001 \\
Average daily gain $(\mathrm{kg})$ & $0.62 \pm 0.05^{\mathrm{b}}$ & $0.87 \pm 0.05^{\mathrm{a}}$ & 0.01 \\
\hline
\end{tabular}

G1: Fed on concentrate feed mixture (CFM) plus corn silage (CS) at a ratio of 1:3; G2: fed on CFM only during the finishing period>

Table 3. Carcass traits (mean $\pm \mathrm{SE}$ ) of Baladi bullocks as affected by type of feeding during finishing period

\begin{tabular}{lccc}
\hline Item & G1 & G2 & P value \\
\hline Carcass weight $(\mathrm{kg})$ & $240.0 \pm 4.0^{\mathrm{a}}$ & $240.2 \pm 3.6^{\mathrm{a}}$ & 0.3 \\
Dressing \% & $56.0 \pm 1.3^{\mathrm{a}}$ & $55.2 \pm 0.6^{\mathrm{a}}$ & 0.2 \\
Boneless meat \% & $46.4 \pm 1.2^{\mathrm{a}}$ & $45.6 \pm 1.0^{\mathrm{a}}$ & 0.2 \\
Meat/ bone ratio & $4.4 \pm 0.1^{\mathrm{a}}$ & $4.5 \pm 0.1^{\mathrm{a}}$ & 0.4 \\
Eye muscle area $\left(\mathrm{cm}^{2}\right)$ & $70.02 \pm 3.8^{\mathrm{a}}$ & $74.3 \pm 5.1^{\mathrm{a}}$ & 0.8 \\
Rib cut components (\%) & & & \\
$\quad$ Lean & $64.6 \pm 1.5^{\mathrm{a}}$ & $60.1 \pm 1.8^{\mathrm{a}}$ & 0.2 \\
$\quad$ Bone & $18.2 \pm 1.2^{\mathrm{a}}$ & $21.1 \pm 1.4^{\mathrm{a}}$ & 0.3 \\
$\quad$ Fat & $17.2 \pm 2.1^{\mathrm{a}}$ & $18.8 \pm 1.2^{\mathrm{a}}$ & 0.6 \\
\hline
\end{tabular}

G1: Fed on concentrate feed mixture (CFM) plus corn silage (CS) at a ratio of 1:3; G2: fed on $\mathrm{CFM}$ only during the finishing period

The obtained ADG during the finishing period of G2 (fed on concentrate feed mixture) is less than that reported by El-Bedawy et al. (1996) and El-Asheeri (2008) 
$(0.9-1.02 \mathrm{~kg} /$ day) under the same feeding type. The ADG of G1 (fed on corn silage) is also less than that reported by El-Asheeri et al. (2008) (0.72 kg) during the corresponding period of animals fed on concentrate feed mixture and corn silage at a ratio of 1:3. The difference between present study and previous ones is most probably attributed to the ADG in the present work was calculated based on the finishing period, while the previous ones were measured based on the whole fattening period.

Obtained values of dressing and boneless meat percentages of G1 and G2 come in agreement with those reported previously by Sadek et al. (1993), El- Bedawy et al. (1996) and El-Asheeri et al. (2008) (56 - 58\% and 46-48\% for dressing and boneless meat percentage, respectively). The obtained eye muscle area $\left(70.02-74.3 \mathrm{~cm}^{2}\right)$ is close to that reported by El-Asheeri et al. (2008) $\left(70.0-71.1 \mathrm{~cm}^{2}\right)$ while less than that reported by El-Bedawy et al. (1996) on the same breed.

The physical components of rib cut (bone, lean and fat tissues, table 3) are also close to that reported by El-Asheeri et al. (2008) (18.3, 64.6 and 17.1\%, for bone, lean and fat tissues, respectively) while less than that reported by El-Bedawy et al. (1996) on Baladi bullocks slaughtered between 410 - $425 \mathrm{~kg}$ for in bone and lean $(9.8$ and, $67.9 \%$, respectively) while higher in fat $22.3 \%$.

\section{Physical traits:}

Physical traits of the two studied groups ( $\mathrm{pH}$ - before and after chilling; expressible fluid $\%$; cooking loss $\%$ and shear force) values were insignificantly different, indicating no effect of feeding corn silage during finishing period on the studied traits (Table 4). However, it is worth to note that $\mathrm{pH}$ tended to decrease after chilling by 0.06 to 0.16 compared to $\mathrm{pH}$ before chilling. Percentage of decrease in $\mathrm{pH}$ after $24 \mathrm{~h}$ of slaughter was 2.0 and $2.6 \%$ for G1 and G2, respectively.

Table 4. Physical characteristics (Mean \pm SE) of Baladi bullocks as affected by type of feeding during finishing period $\quad(n=6 /$ group)

\begin{tabular}{lccc}
\hline Trait & G1 & G2 & P value \\
\hline pH- before chilling & $6.16 \pm 0.11^{\mathrm{a}}$ & $6.26 \pm 0.06^{\mathrm{a}}$ & 0.16 \\
pH- after chilling (24hr) & $6.04 \pm 0.10^{\mathrm{a}}$ & $6.1 \pm 0.05^{\mathrm{a}}$ & 0.63 \\
Expressible fluid (\%) & $30.0 \pm 1.76^{\mathrm{a}}$ & $32.4 \pm 2.16^{\mathrm{a}}$ & 0.36 \\
Cooking loss (\%) & $44.3 \pm 1.04^{\mathrm{a}}$ & $43.8 \pm 1.34^{\mathrm{a}}$ & 0.54 \\
Shear force values (kgf) & $4.36 \pm 0.35^{\mathrm{a}}$ & $4.14 \pm 0.18^{\mathrm{a}}$ & 0.5 \\
\hline
\end{tabular}

G1: Fed on concentrate feed mixture (CFM) plus corn silage (CS) at a ratio of 1:3; G2: fed on CFM only during finishing period.

The obtained values of cooking loss (Table 4) are close to those reported for Baladi bullocks (El-Bedawy et al., 1996), being 42.2 - $44.3 \%$, while they are higher than those reported by Wheeler et al. (1990) and Serra et al. (2008), being $22.9-25.3$ $\%$. The difference in values of cooking loss between the present values and those reported for other breeds are most probably attributed to genotype. The trends of the results of cooking loss of the two studied groups agree with the results obtained by Faucitano et al. (2008) who found that cooking loss was higher when cattle fed on grass silage compared to those fed on a combination of grass silage and concentrate.

The non-significant difference of shear force between the two studied groups agrees with the findings of French et al. (2000) who reported no effect of feeding corn silage on shear force values compared to those feeding grains. The obtained values of shear force in the two studied groups $(4.14-4.36 \mathrm{~kg} /$ force $)$ are higher than 
that reported by Crouse et al. (1984) for L. dorsi (3.8 kg/ force). The slow decrease in $\mathrm{pH}$ after $24 \mathrm{~h}$ post-slaughter gives a reasonable explanation of higher values of shear force, which is being less when $\mathrm{pH}$ decreased to less than 5.45 (Wulf and Page, 2000). On the contrary, the present findings disagree with the results of Radunz et al. (2003) reporting a significant effect of type of feed on tenderness.

The obtained values of cooking loss $(43.8-44.3 \%)$ is close to that reported for Baladi bullocks (El-Bedawy et al., 1996 \& 2004), being 42.2 - $44.3 \%$ ), while they were higher than those reported by Wheeler et al. (1990) and Serra et al. (2008), being 22.9 - $25.3 \%$ for Avileña-Negra Ibérica, Bruna dels Pirineus and Morucha breeds.

The difference in values of cooking loss between the present values and those reported for other breeds are most probably attributed to genotype. The trend of the results of cooking loss of the two studied groups agrees with the results of Faucitano et al. (2008) who found that cooking loss was higher when cattle fed on grass silage compared to those fed on a combination of grass silage and concentrate.

Bidner et al. (1981) and Crouse et al. (1984) also reported that feeding on forage resulted in darker meat compared to those fed on grains, which is in contrast with the present findings.

\section{Chemical traits:}

The studied chemical traits (moisture, protein, fat, and collagen) (Table 5) and color of meat (lightness, redness and yellowness) (Table 6) were similar in G1 and G2 with no significant differences. It is of interest to note that all color traits of G2 were higher than of G1 however the differences were non-significant.

The in-significant difference in chemical traits among the two studied groups comes in agreement with the findings of Mills et al. (1992); Nour et al. (1994), ElBedawy et al. (1996); French et al. (2000) and Jenschke et al. (2008) who reported that feeding type had no effect on chemical composition of meat. The higher value of collagen in G1 may be the cause of increasing shear force values relative to G2.

Table 5. Chemical analysis (Mean $\pm \mathrm{SE}$ ) of Baladi bullocks as affected by type of feeding during finishing period

\begin{tabular}{lccc}
\hline Trait & G1 & G2 & P value \\
\hline Moisture (\%) & $71.69 \pm 0.45^{\mathrm{a}}$ & $71.59 \pm 0.83^{\mathrm{a}}$ & 0.432 \\
Protein (\%) & $22.11 \pm 0.41^{\mathrm{a}}$ & $22.35 \pm 0.46^{\mathrm{a}}$ & 0.720 \\
Fat (\%) & $3.17 \pm 0.30^{\mathrm{a}}$ & $2.94 \pm 0.55^{\mathrm{a}}$ & 0.379 \\
Collagen (\%) & $1.39 \pm 0.15^{\mathrm{a}}$ & $1.19 \pm 0.15^{\mathrm{a}}$ & 0.299 \\
\hline
\end{tabular}

G1: Fed on concentrate feed mixture (CFM) plus corn silage (CS) at ratio of 1:3; G2: Fed on CFM only during finishing period

Table 6. Minolta color values (mean \pm SE) of Baladi bullocks meat as affected by type of feeding during finishing period $(n=6 /$ group)

\begin{tabular}{lccc}
\hline Traits & G1 & G2 & P value \\
\hline L (Lightness) & $41.18 \pm 0.87$ & $43.68 \pm 0.93$ & 0.093 \\
A* (Redness) & $14.93 \pm 0.97$ & $17.44 \pm 1.81$ & 0.127 \\
B* (Yellowness) & $4.67 \pm 0.52$ & $8.40 \pm 1.14$ & 0.643 \\
\hline
\end{tabular}

G1: Fed on concentrate feed mixture (CFM) plus corn silage (CS) at a ratio of 1:3; G2: fed on CFM only during the finishing period. 


\section{Economic traits:}

Although, no significant difference was observed between G1 and G2, cost of feed/ $\mathrm{kg}$ gain of $\mathrm{G} 2$ was less $(\mathrm{P}<0.05)$ than of $\mathrm{G} 1$ by $22.8 \%$. Similar trend was observed in total feed cost of finishing period, which was less $(\mathrm{P}<0.002)$ in $\mathrm{G} 2$ than G1 by $30.4 \%$ (Table 7).

Table 7. Economic indicators (mean \pm SE) of Baladi bullocks as affected by type of feeding during finishing period $\quad(n=8 /$ group $)$

\begin{tabular}{lccc}
\hline Traits & G1 & G2 & P Value \\
\hline Feed conversion (kg/ kg gain) & $13.3 \pm 1.2^{\mathrm{a}}$ & $16.6 \pm 1.02^{\mathrm{a}}$ & 0.15 \\
& $(80.1 \%)$ & $(100 \%)$ & \\
Total feeding cost (Egyptian Pound) & $689.8 \pm 52.7^{\mathrm{b}}$ & $991.6 \pm 39.4^{\mathrm{a}}$ & 0.002 \\
(L.E.) & $(69.6 \%)$ & $(100 \%)$ & \\
Cost of feed/kg gain (Egyptian Pound) & $11.2 \pm 1.04^{\mathrm{b}}$ & $14.5 \pm 8.9^{\mathrm{a}}$ & 0.05 \\
(L.E.) & $(77.2 \%)$ & $(100 \%)$ & \\
\hline
\end{tabular}

G1: Fed on CFM plus CS at ratio of 1:3; G2: Fed on CFM only during finishing period Percentage values of G1 were calculated relative to G2

L.E.: Egyptian bound

Cost of producing $1 \mathrm{~kg}$ weight gain during the finishing period in G1 and G2 are higher than the cost of producing $1 \mathrm{~kg}$ weight gain during whole fattening period using the same ration by about $20 \%$ (El-Asheeri et al., 2008). This is attributed to the lower ADG during the finishing relative fattening period (El-Asheeri, 2008).

\section{CONCLUSION}

In conclusion, feeding Baladi bullocks during the finishing period on corn silage has no negative effect on physical and chemical traits of gained meat. In addition, feeding Baladi bullocks on corn silage during the finishing period reduces the cost of $1 \mathrm{~kg}$ gain compared to finishing on concentrate feed mixture.

\section{REFERENCES}

A.O.A.C., 1990. Association of Official Analytical Chemists: Official Methods of Analysis, $15^{\text {th }}$ Ed., Washington, D. C., USA.

Bidner T.D., A.R. Schupp, R.E. Montgomery and J.C. Jr. Carpenter, 1981. Acceptability of beef finished on all-forage, forage-plus-grain or high energy diets. Journal of Animal Science, 53:1181- 1187.

Chambaz A., M.R.L. Scheeder, M. Kreuzer, and P. A. Dufey, 2003. Meat quality of Angus, Simmental, Charolais and Limosim steers copared at the same intramuscular fat content. Meat Science, 36: 491- 500.

CIE (Commission International de l'E' clairage), 1976. Official recommendations on uniform color spaces. Color difference equations and metric color terms, Suppl. No. 2. CIE Publication No. 15 Colourimetry. Paris.

Crouse J.D., H.R. Cross, and S. C. Seideman, 1984. Effects of a grass or grain diet on the quality of three beef muscles. Journal of Animal Science, 58:619-625.

El-Asheeri Amal, K., 2008. Profitability of Baladi calf feedlots under different fattening systems. Egyptian Journal of Animal Production, 45 (supplement issue): $57-67$. 
El-Asheeri Amal K., A. S. Sami, and M. A. Radwan, 2008. Biological performance and economic indicators of fattened Baladi bullocks under two fattening systems. Egyptian Journal of Animal Production, 45 (supplement issue): 69-77.

El- Bedawy T. M., M. A. I. Salem, and E. A. Badr, 1996. Effect of dietary fat on growth performance and carcass characteristics of finishing bulls. Egyptian Journal of Animal Production, 33 (Supplement issue): 103-111.

El- Bedawy T. M., M. A. I. Salem, and A. S. Sami, 2004. Calcium soaps in low or high roughage rations: 2- Effect on growth performance, carcass characteristics and meat quality of growing finishing Baladi bulls. Journal of Animal Production, 41: 61-71.

Faucitano L., P. Y. Chouinard, J. Fortin; I. B. Mandell, C. Lafrenière, C. L. Girard, and R. Berthiaume, 2008. Comparison of alternative beef production systems based on forage finishing or grain-forage diets with or without growth promotants: 2. Meat quality, fatty acid composition, and overall palatability. Journal of Animal Science, 86:1678-1689.

French P., E. G. O'Riordan; F. J. Monahan, P. J. Caffrey, M. Vidal, M.T. Mooney; D. J. Troy and A. P. Moloney, 2000. Meat quality of steers finished on autumn grass, grass silage or concentrate-based diets. Meat Science, 56:173-180.

Gill R. K., D.L. Van Overbeke, B. Depenbusch, J. S. Drouillard and A. Di Costanzo, 2008. Impact of beef cattle diets containing corn or sorghum distillers grains on beef color, fatty acid profiles, and sensory attributes. Journal of Animal Science. 86:923-935.

Jenschke B. E., J. R. Benton, C. R. Calkins, T. P. Carr, K. M. Eskridge; T. J. Klopfenstein and G. E. Erickson, 2008. Chemical and sensory properties of beef of known source and finished on wet distillers grains diets containing varying types and levels of roughage. Journal of Animal Science. 86:949-959.

Mills E. W., J.W. Comerford, R. Hollender and H. W. Harpster, 1992. Meat composition and palatability of Holstein and beef steers as influenced by forage type and protein source. Journal of Animal Science, 70: 2446-2451.

Mostageer A., Y. Afifi; M. A. Morsy and A. Nigm, 1987. Grading up Baladi cattle with Friesian in Egypt. Journal of Animal Breeding and Genetics: 104, 383-393.

Mostageer A., M. A. Morsy, A. Nigm, N.S. Rashad and F. Pirchner, 1990. Milk production characteristics of Baladi cattle and their F1 crossbreds with some European breeds. Journal of Animal Breeding and Genetics, 107: 301-310.

Nour A.Y. M., L. A. Gomide, E. W. Mills, R.P. Lemenager and M. D. Judge, 1994. Influence of production and postmortem technologies on composition and palatability of USDA select grade beef. Journal of Animal Science, 72:12241231.

NRC, 1996. Nutrient Requirements of beef cattle. National Research Council, National Academy Press, Washington, D. C. Seventh Revised Edition: Update 2000. http://www.nap.edu/catalog/9791.html

O’Sullivan, A., K. Galvin, A.P. Moloney, D. J. Troy, K. O'Sullivan and J. P. Kerry, 2003. Effect of pre-slaughter rations of forage and/ or concentrates on the composition and quality of retail packaged beef. Meat Science. 63:279-286.

Prieto, N., S. Andrés, F.J. Giradles, A.R. Mantecòn and P. Lavìn, 2006. Potential use of near infrared reflectance spectroscopy (NIRS) for the estimation of chemical composition of oxen meat samples. Meat Science, 74:487-496. 
Radunz A.E., G.P. Lardy, M.L. Bauer, M.J. Marchello, E.R. Loe and P.T. Berg, 2003. Influence of steam-peeled potato-processing waste inclusion level in beef finishing diets: Effects on digestion, feedlot performance, and meat quality. Journal of Animal Science. 81:2675-2685.

Sadek R.R., M.A. Morsy, A.A. Nigm, M.A.M. Ibrahim and A.M. Sabry, 1993. The effect of grading up Baladi cattle with Friesian on meat production performance. Egyptian J. Anim. Prod., 30 (2): 143-160.

Sami A. S.,C. Augustini and F.J. Schwarz, 2004. Effects of feeding intensity and time on feed on performance, carcass characteristics and meat quality of Simmental bulls. Meat Science, 67(2): 195-201.

SAS, 2001. SAS institute Inc., Cary, NC. USA.

Serra, X., L. Guerrero, M.D. Guárdia, M. Gil, C. Sañudo, B. Panea, M. M. Campo, J.L. Olleta, M.D. García-Cáchan, J. Piedrafita and M. A. Oliver, 2008. Eating quality of young bulls from three Spanish beef breed-production systems and its relationships with chemical and instrumental meat quality. Meat Science, 79: 98104.

Shackelford S.D., T.L. Wheeler and M. Koohmaraie, 1999. Tenderness classification of beef: II. Design and analysis of a system to measure beef Longissimus shear force under commercial processing conditions. Journal of Animal Science, 77:1474-1481.

Shackelford S.D., T.L. Wheeler and M. Koohmaraie, 2004. Evaluation of sampling, cookery, and shear force protocols for objective evaluation of lamb Longissimus tenderness. Journal of Animal Science, 82:802-807.

Tøgersen G., J.F. Arnesen; B. N. Nielsen and K. I. Hildrum, 2003. On-line prediction of chemical composition of semi-frozen ground beef by non-invasive NIR spectroscopy. Meat Science.63: 515-523.

Wheeler T. L., J. W. Savell; H. R. Cross, D. K. Lunt and S. B. Smith, 1990. Effect of postmortem treatments on the tenderness of meat from Hereford, Brahman and Brahman-cross beef cattle. Journal of Animal Science, 68:3677-3686.

Wulf D.M. and J.K. Page, 2000. Using measurements of muscle color, $\mathrm{pH}$, and electrical impedance to augment the current USDA beef quality grading standards and improve the accuracy and precision of sorting carcass into palatability groups. Journal of Animal Science, 78:2595-2607. 
تأثير التظذية على سيلاج الذرة خلال فترة التشطيب (إنهاء التسمين) على الصفات الطبيعية والكيميائية للحوم العجول البلاية علية الترد

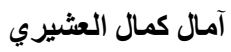 \\ قسم الإنتاج الحيواني، كلية الزراعة، جامعة القاهرة
}

في هذه التجربة تم إستخدام عدد 17 عجل بقري بلدي بهدف دراسة تأثير التخذية علي سيلاج الذرة خلال

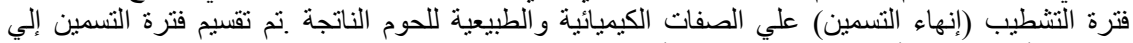

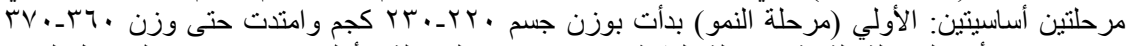

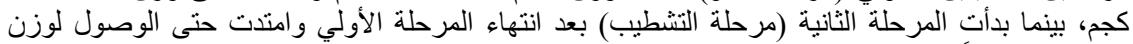

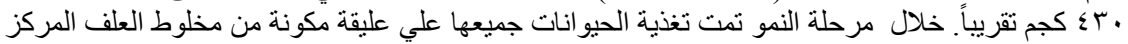

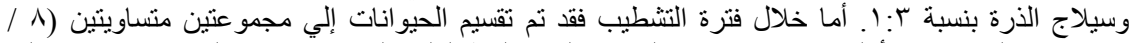

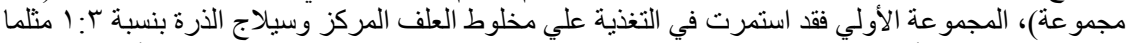

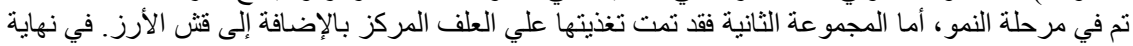

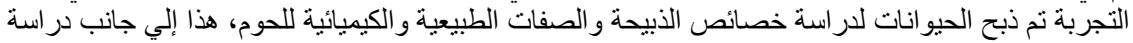

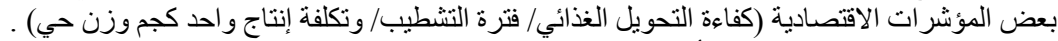

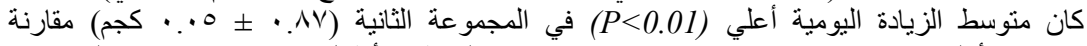

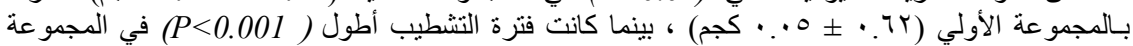

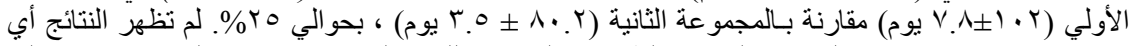

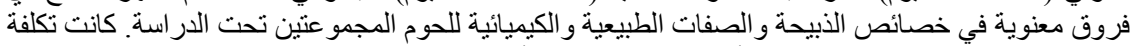
التغذية لإنتاج واحد كجم وزن حي أقل في المجموعة الأولي ( $\%$ \% 9.0

من النتائج السابقة يمكن استتناج أن تغذية عجول الأبقار البلدية خلال فترة التشطيب علي سيلاج الذرة قد أدى إلي تحسين إيجابي فى المؤشر التخات الإقتصادية، دون الثأثير علي جودة اللحوم الناتجة. 